his credit, including reaction patents for wireless receiver circuits, the early British broadcasting stations, directional receiving systems for long-wave communication circuits, rotating beam aerials, shortwave wireless transmitting and receiving circuits, and in particular the beam aerial array associated with his name, which was the fundamental invention comprised in the beam system of wireless telegraphy. $\mathrm{He}$ also developed the concentric cable system, which is essential in television transmission practice. Mr. Franklin was the first recipient of the James Alfred Ewing Medal, instituted in 1936 in memory of Sir Alfred Ewing and awarded by the Institution of Civil Engineers for specially meritorious contributions to the science of engineering in the field of research.

\section{American Association for the Advancement of} Science : New President

Prof. Boger ADams, head of the Department of Chemisty in the University of Illinois, has been appointed president-elect of the American Association for the Advancement of Science, and will serve as prosident during 1950. A former president of the American Chemical Society, Prof. Adams has received many honours for his work as a teacher and his research achievements in synthetic organic chemistry, including the Davy Medal of the Royal Society in 1945 (see Nature, 156, 695; 1945). The president of the Association for 1949 is Prof. Elvin C. Stakman, professor of plant pathology in the University of Minnesota. The next meeting of the Association will be held in New York during Christmas week.

\section{T. L. ' Beddoes (1803-49)}

Thomas hovele Bedpoes, who died by his own hand a cent fogo on January 26,1849 , is an intriguing exam 18 of medical man in whom-to use Sir Arthur LacN 1 y's striking phrase-the twin herit ages of Apollo (medicine and poetry) were always sating for the mastery. Eldest son of the eccentric Bristol physician, Thomas Beddoes, and nephew of the novelist Maria Edgeworth, he was born at Clifton on July 20, 1803. Educated at Bath Gram. mar School, at Charterhouse, and at Pembroke College, Oxford, he published "The Improvisatore" while an undergraduate; but it was "The Bride's Tragedy" that won the praise of the critics in 1822 . Abandoning literature for medicine, be went to Göttingen three years later, and as a medical student sat at the feet of Blumenbach, Langenbeck, and Stromeyer. After graduating M.D. at Würzburg in 1832, he practised in Germany and in Zurich. For a time he was engrossed in experimental physiology, and he translated R. D. Grainger's "Observations on ... the Spinal Cord" into German ; his translation apparently was never published. Towards the end of his life his mind became clouded, and there is some evidence to suggest that he inflicted a wound on his left leg, which became gangrenous and had to be amputated. While in hospital at Basle, he took his own life with curare, though apoplexy was recorded as the official cause of death. His macabre play, "Death's Jest-Book", was published in the following year. Despite its extravagant and unbalanced moods, Beddoes' poetry shows true lyrical greatness.

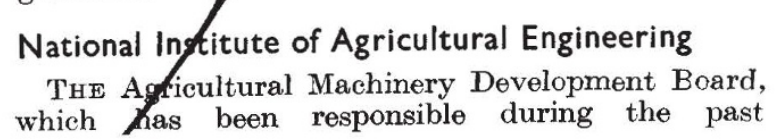

seven years for advising on research and development work on agricultural mechanization and on the management of the National Institute of Agricultural Engineering, is now being replaced by a new and independent governing body of the National Institute of Agricultural Engineering. This body will be constituted legally as a company limited by guarantee and without share capital, and will receive grant aid from the Ministry of Agriculture and the Department of Agriculture for Scotland. The headquarters station of the old Institute at Wrest Park and its Scottish station at Howden will be continued under the new organisation. The members of the governing body, consisting of a chairman and twelve members, have been appointed jointly by the two Agricultural Ministers with the advice of the Agricultural Research Council. Communications should be addressed to the Secretary, Ministry of Agriculture and Fisheries, 1-4 Cambridge Terrace, Regent's Park, London, N.W.1.

In accordance with a recommendation of the Agricultural Machinery Development Board, the Minister of Agriculture and the Secretary of State for Scotland have appointed an Agricultural Machinery Advisory Committee, which will be a permanent body and will consist of representatives of the agricultural and agricultural engineering industries and of the interested Government Departments. Communications should be sent to Col. C. K. Hamilton, Ministry of Agriculture and Fisheries, 14-21 Chester Terrace, Regent's Park, London, N.W.1.

The National Central Library

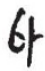

TeE thirty-segond annual report of the executive committee pine National Central Library, covering the year en ing February 29, 1948, again refers to a consid Arabl increase in the services of the Library to All the categories of libraries with which it is in colperation. Issues from or through the Library during the year reached 84,889 , an increase of 28.6 per cent on the previous year ; of these, 8,655 were to university libraries, as against 6,073 in $1946-47$, and 7,823 to the libraries of Government departments, research and industrial organisations, etc. Issues from the Scottish Central Library for Students increased from 13,690 to 15,547 , and from the Irish Central Library for Students from 12,893 to 13,082 . Twelve further special libraries have been added to the group of "Outlier Libraries", which now numbers 189 , and 15,023 books were lent by these libraries during the year, as against 11,289 in the previous year. There are now 589 libraries co-operating in the regional systems and in the London borough libraries interlending system, and 142,832 books were lent by these libraries to other libraries in their own system during the year, as against 120,992 in 1946-47. Loans to foreign libraries during the year increased to 325 , and 82 books were borrowed by British libraries from foreign sources. The Bureau of American Bibliography continues to demonstrate its value as the main source of information about American books and periodicals, and 123,270 further entries were made during the year in the main catalogues of the National Central Library, in Wales and in Scotland. Steady progress is now being made with the Union Catalogue of Russian Books and Periodicals, and the Library has also added to its activities that of a National Book Centre to coordinate the interchange and distribution of otherwise 'unwanted' publications. The report stresses the 


\section{No. 4134 January 22, $1949 \quad$ N A T U R E}

serious position caused by the continued shortage in book production, and records some increase in staff and a start on preventive repairs on the devastated portion, of the building at Malet Place, London.

\section{Spiritual Approach coferysics *}

UNDER the itid whe Value of the Individual", Mr. F. In C.AR Jlins, in Occasional Paper No. 5 of the $\mathrm{B}$ riti $\mathrm{A}$ Social Hygiene Council, asks physicists to lof fyond their immediate pre-occupations. Physical science, he argues, arrives at a point where it can go no further; but this does not justify the assumption that there is nowhere further to go. Modern physical theory cannot (with Laplace) postulate a universe which is a self-maintaining system, about the origins or destiny of which it is superfluous to inquire. The step from physics to theology is not compulsory; but there is nothing to prevent it and a good deal to encourage it. Only when that step is taken can the universe be seen as an environment with a meaning, where human personality is able tiprealize itself.

\section{Anatoliy and Physiology of Acrididæ}

UNDER the title af "Recent Advances in Acridology", Dr. B. PNUvarov contributes a general survey of the lite? locusts And grasshoppers. It covers the period that hgs elapsed since the publication of the same author's b6 "Locusts and Grasshoppers", in 1928. During the interval of twenty years the titles of nearly 2,500 papers, published in twelve languages, have been added to the bibliography that is kept up to date at the Anti-Locust Research Centre in London. The present survey is intended to provide a digest of all publications bearing upon anatomy and physiology. Other surveys dealing in particular with development, ecology, control, etc., will follow. The object of these digests is to further research and investigation by making the relevant literature more easily found. Particular attention has been paid to collating widely scattered data and papers that are not readily accessible. The present survey appeared, under the title given above, in the Transactions of the Royal Entomological Society of London, vol. 99, Part 1, pp. 1-75, 1948, and has been reprinted as "AntiLocust Bulletin No. 1" by the Anti-Locust Research Centre, British Museum (Natural History), London, S.W.7. It is to be obtained in exchange from the Anti-Locust Centre, or may be purchased from the Royal Entomological Society, 41 Queen's Gate, London, S.W.7 (price £1 4s.).

\section{Physical Society : Meeting at Edinburgh}

A ONE-DAY meeting of the Physical Society will be held on Febriary 19 at the University of Edinburgh, in the Department of Natural Philosophy. The morning ossion will include three papers on developments ifelectron focusing : T. H. Braid and H. O. W. Richgdason will describe tests of a wide-angle $\beta$-particle spectrometer; R. E. Siday and D. A. Silverston will discuss tests of a prism spectrograph; and A. N. Barker, Prof. N. Feather and H. O. W. Richardson will describe an emission microscope for photo-electron autoradiography. A paper on the use of proportional counters to investigate $\beta$-disintegration will be given by $\mathrm{S}$. C. Curran, and \& paper on electrons as nuclear projectiles by $B$. Touschek. In the afternoon session, subjects to be discussed are: a new approach to the theory of elementary particles, by Prof. M. Born and H. S.
Green; film transport in liquid helium II, by Prof. J. F. Allen; a new photo-electric amplifier, by R. V. Jones; and long-range molecular forces, by J. Iball.

\section{Announcements}

Sir Hargld Spencer Jones, Astronomer Royal, has been awarded the Catherine Wolfe Bruce Gold Medal for 1949 of the Astronomical Society of the Pacific, for distinguished services to astronomy.

Prof. P. M. S. BLacketT, Langworthy professor of physics inthe University of Manchester, has been awarded the Dalton Medal of the Manchester Literary and Phirosophical Society, in recognition of his outstanding contributions to the advancement of our knowledge of physics. This Medal has been awarded on six previous occasions, as follows: Edward Schunck (1898), Sir Henry Roscoe (1900), Prof. Osborne Reynolds (1913), Sir Ernest (Lord) Rutherford (1919), Sir J. J. Thomson (1931), Sir Lawrence Bragg (1942). The presentation will take place.at a conversazione with which the Society will open the new session in October 1949.

The first award of the "Medal for Service in Agriculture and Forestry" of the Institute for International Relations in Agriculture and Forestry in Prague has been made to Prof. Dontcho Kostoff, direct r of the Institute for Applied Biology and Organic Development at the Academy of Sciences, Sofia, and professor of plant breeding and evolution in the Faculty of Agronomy, for his monograph, "Cytogenetics of the Genus Nicotiana (1941/1943)", on the ground that it is the most noteworthy book in the Slavonic languages published during the last few years.

Mr. J. W. Tullo has retired from the post of chief ghemist to Messrs. Arthur Guinness, Son and Co. Ltd., Dublin, with whom he has been associated for the past fifty years. He has been succeeded by Mr. J. Andrews.

Dr. F. A. Fox, deputy director of the British Welding Research Association, has been appointed deputy technical manager of Messrs. H. J. Enthoven and Sons, Ltd., London, E.C.3.

The Fifty-fifth Conference of the Deutsche Gesellschaft für innere Medizin is due to take place in Wieshaden during April 25-28, 1949. The chief thomes for discussion will be: protein exchange; chemotherapy ; circulation problems; and psycho. somatic medicine and neuritis.

A coynse of six lectures on "Electronics in Industy" will be given at the Electrical Engineering Department of The Polytechnic, 309 Regent Street, London, W.1, by Mr. L. I. Farran. The lectures will be given on Fridays at 6.30 p.m., commencing February 4,1949 , and the fee for the course is $10 s$.

THE University of Oxford has accepted the generousgift from the American Cyanamid Company, Stamford, Connecticut, of a Perkin Elmer infra-red spegtrometer with recorder and accessories. This has been installed in the Physical Chemistry Laboratory under the supervision of Dr. H. W. Thompson, and will be used for spectroscopic investigations of a fundamental character, and particularly with regard to problems of biochemical importance. In the latter connexion it is hoped to undertake co-operative work between several of the University laboratories at Oxford. 